\title{
Restinga forests of the Brazilian coast: richness and abundance of tree species on different soils
}

\author{
LUIZ F.S. MAGNAGO ${ }^{1}$, SEBASTIÃO V. MARTINS ${ }^{2}$, CARLOS E.G.R. SCHAEFER ${ }^{3}$ and ANDREZA V. NERI ${ }^{1}$ \\ ${ }^{1}$ Universidade Federal de Viçosa, Departamento de Biologia Vegetal, \\ Avenida Peter Henry Rolfs, s/n, Campus Universitário, 36570-000 Viçosa, MG, Brasil \\ ${ }^{2}$ Universidade Federal de Viçosa, Departamento de Engenharia Florestal, \\ Avenida Peter Henry Rolfs, s/n, Campus Universitário, 36570-000 Viçosa, MG, Brasil \\ ${ }^{3}$ Universidade Federal de Viçosa, Departamento de Solos, \\ Avenida Peter Henry Rolfs, s/n, Campus Universitário, 36570-000 Viçosa, MG, Brasil \\ Manuscript received on August 23, 2011; accepted for publication on October 11, 2011
}

\begin{abstract}
The aim of this study was to determine changes in composition, abundance and richness of species along a forest gradient with varying soils and flood regimes. The forests are located on the left bank of the lower Jucu River, in Jacarenema Natural Municipal Park, Espírito Santo. A survey of shrub/tree species was done in 80 plots, $5 \times 25 \mathrm{~m}$, equally distributed among the forests studied. We included in the sampling all individuals with $\geq 3.2 \mathrm{~cm}$ diameter at breast height $(1.30 \mathrm{~m})$. Soil samples were collected from the surface layer $(0-10 \mathrm{~cm})$ in each plot for chemical and physical analysis. The results indicate that a significant pedological gradient occurs, which is influenced by varying seasonal groundwater levels. Restinga forest formations showed significant differences in species richness, except for Non-flooded Forest and Non-flooded Forest Transition. The Canonical Correlation Analysis (CCA) showed that some species are distributed along the gradient under the combined influence of drainage, nutrient concentration and physical characteristics of the soil. Regarding the variables tested, flooding seems to be a more limiting factor for the establishment of plant species in Restinga forests than basic soil fertility attributes.
\end{abstract}

Key words: Vegetation, Flooded Forests, Coastal ecosystem, Sandy Soils, Quaternary deposits, Marine influence, Riparian forests.

\section{INTRODUCTION}

Marine regressions and transgressions following sea level changes during the Quaternary period allowed the formation of beach ridges, dunes and interdunes along the Brazilain coast (Martin et al. 1997). These depositional features were formed during the Late Pleistocene and Holocene epochs, forming extensive sandy coastal plains, with major deposition of mature

Correspondence to: Luiz Fernando Silva Magnago

E-mail: luiz_fsm@hotmail.com quartz sands and local contributions of fluvial sands, especially near large river estuaries (Pereira 2003). On these sandy coastal plains we find the Restinga ecosystem (Araujo et al. 1998) occupying nearly $80 \%$ of the Brazilian coastal fringe, or about $7110 \mathrm{~km}$ (Suguio and Tessler 1984). This ecosystem is associated with the Atlantic Rain Forest biome (Coutinho 2006).

The topographical differences among the beach ridges, dunes and interdunes in the Restinga are associated with different groundwater levels, 


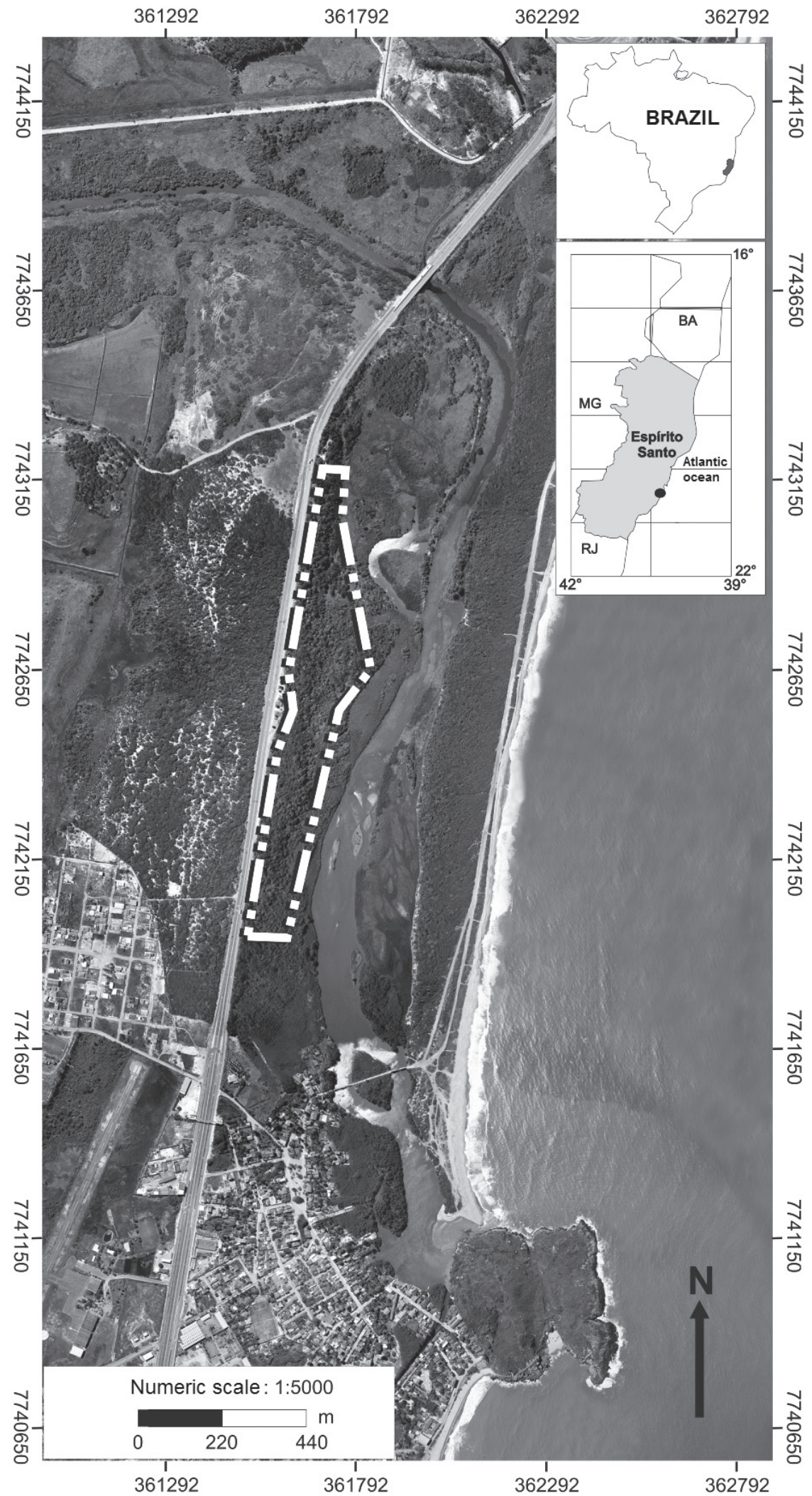

Figure 1 - Location of Jacarenema Natural Municipal Park, Vila Velha/ES with the the studied areas highlighted. 
resulting in varying pedological conditions, which can, among other factors, lead to the heterogeneity of vegetation types in the Brazilian Restinga.

According to ter Braak and Prentice (1988), biotic communities show greater development in the narrow confines of their optimum, varying with the existence of physical gradients. Among the abiotic factors, physical, chemical and soil drainage characteristics have been widely cited as important factors for the distribution of plant species in communities of tropical environments (Lathwell and Grove 1986, Oliveira-Filho et al. 1994, Clark et al. 1999, Budke et al. 2007, FerreiraJunior et al. 2007). Thus, the various interactions between abiotic factors and their responses in species composition result in high environmental heterogeneity, determining the existence of a mosaic of habitats (Machado et al. 2008, Petty and Douglas 2010).

Soil physical, chemical and hydrological conditions also impose variations in species richness of a given area (Sollins 1998), acting on species selection in such a way that local richness varies depending on the degree of influence of environmental variables (Oliveira-Filho et al. 1994, Ivanauskas and Rodrigues 2000, Budke et al. 2007). However,our knowledge on the relationship between vegetation characteristics and soil factors is patchy, and further studies focusing on indicator species
(Jacomine 2004) will be important for a better understanding of Restinga ecosystems, since none of them have been carried out in Brazil.

Thus, we aimed to determine the relationship between vegetation variables, such as composition, abundance and species richness, and soil attributes along a forest gradient in a Restinga.

\section{MATERIALS AND METHODS}

\section{STUDY AREA}

The study area is located in Barra do Jucu, Espírito Santo State, Brazil. The Jacarenema Natural Municipal Park (PNMJ) has an area of 307 hectares (IPEMA 2005), and is located near coordinates $20^{\circ} 26^{\prime} 25^{\prime \prime} \mathrm{S}$ and $40^{\circ} 18^{\prime} 45^{\prime \prime} \mathrm{W}$ (Figure 1). The climate is classified as Aw tropical by Köppen, with hot, wet summers and cold, dry winters.

The forest sites are located on the left bank of the Jucu River, forming an environmental gradient ranging from interdune (River Jucu site) to the innermost dune facing the continent. The varying topographic condition creates different levels of flooding, caused by seasonal floods of the Jucu River, with an accompanying soil gradient (Table I). The terminology for classifying Restinga vegetation types (physiognomies) was based on Pereira (2003), as follows: Well-drained Forest, Transitional Forest, Floodplain Forest and Inundated Forest (Figure 2).

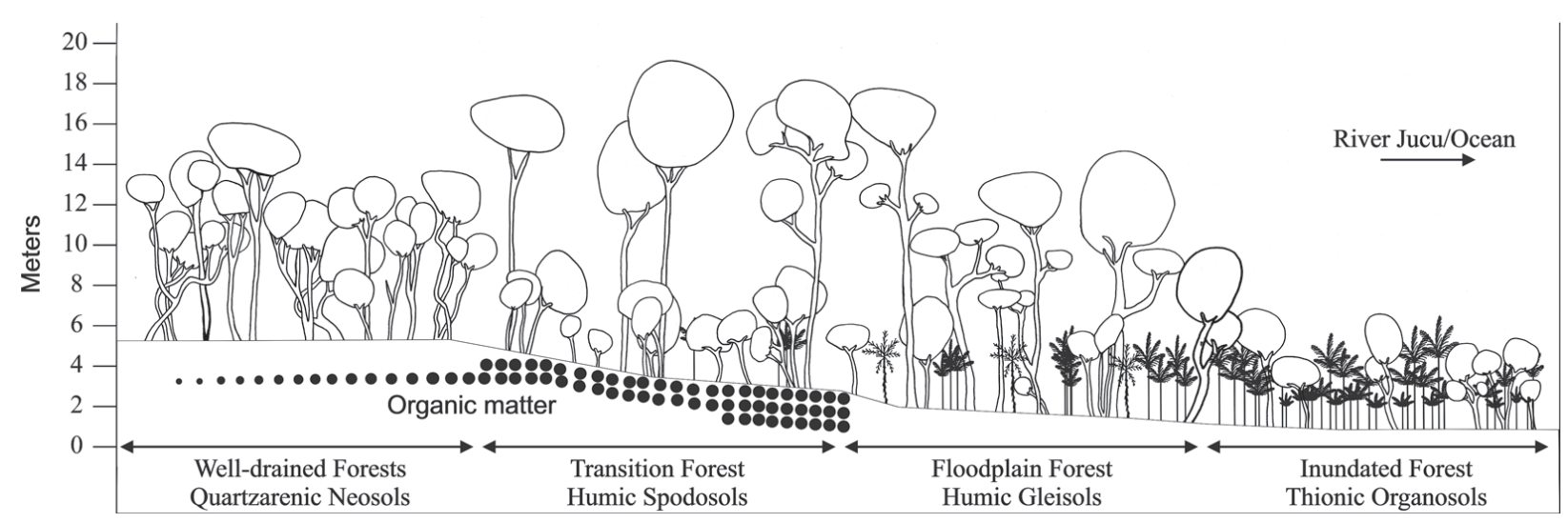

Figure 2 - Schematic profile perpendicular to the River Jucu in Jacarenema Natural Municipal Park, Vila Velha, Brazil. 
TABLE I

Soil classes and groundwater fluctuation in the four forests of Jacarenema Natural Municipal Park, Vila Velha, Brazil. INF=Inundated Forest; FPF=Floodplain Forest; TRF=Transitional Forest; WDF=Well-drained Forest. TH=Thiomorphic Histosols; MG=Melanic Gleysols; HS=Humic Spodosols; QN= Quartzarenic Neossols.

\begin{tabular}{cccccc}
\hline \multirow{2}{*}{ Vegetation type } & \multirow{2}{*}{ Soil classes } & Classes of soil drainage & \multicolumn{3}{c}{ Fluctuation of groundwater (m) } \\
\cline { 4 - 6 } & & & Max & Min & Annual Average \\
\hline INF & TH & Very poorly drained & 0.60 & -0.05 & 0.25 \\
FPF & MG & Poorly drained & 0.15 & -0.30 & -0.06 \\
TRF & HS & Moderately drained & -0.90 & -1.60 & -1.23 \\
WDF & QN & Excessively drained & -3.70 & -5.00 & -4.22 \\
\hline
\end{tabular}

\section{VEGETATION DATA}

The floristic composition of shrub and tree species was determined in 80 plots (Mueller-Dombois and Ellenberg 1974), 5x25 m (125 $\left.\mathrm{m}^{2}\right)$, totaling one hectare of sample area. The plots were equally distributed in the four forest formations, i.e., 20 plots for each forest type, with a minimum spacing of $2 \mathrm{~m}$ apart. We aimed to represent the core areas of each forest when allocating the plots in the phytocoenoses. The plots were arranged in each physiognomy parallel to the Jucu River bank. We recorded shrub and tree species with diameter at breast height $(1.30 \mathrm{~m}) \geq 2 \mathrm{~cm}$.

The palms Bactris setosa and Bactris vulgaris have a caespitose growth habit, forming clumps. The former species occurs in wetlands in large populations (Reis 2006), rendering the separation of each individual virtually impossible. Thus, for this study each stipe was considered to be an individual.

The plant material was determined by consulting the CVRD Herbarium (Vale do Rio Doce), the VIES Herbarium (Universidade Federal do Espírito Santo) and the MBML Herbarium (Museu de Biologia Prof. Mello Leitão). Consultations were also made of specific literature and material was sent to specialists. Fertile specimens were deposited in the collection of the VIES Herbarium (Universidade Federal do Espírito Santo). The species were classified in their respective families according to Angiosperm Phylogeny Group II (APG II 2003).
SOIL SAMPLE

Soil samples were collected for chemical and physical analysis taking three replicates of surface soil $(0-10 \mathrm{~cm})$ in each sample unit, for a total of 40 samples. The samples were air-dried and sieved with a $2 \mathrm{~mm}$ diameter mesh. These samples were analyzed in the Soil Analysis Laboratory, Department of Soils, Universidade Federal de Viçosa. The soil and drainage classes of each physiognomy were classified according to the Brazilian System of Soil Classification (EMBRAPA 2006).

\section{DATA ANALYSIS}

Differences in species richness and chemical and physical soil attributes between the four forests were tested by the analysis of variance (one way ANOVA). Subsequently, we used the Tukey test to determine significant differences between areas. In addition, we employed the Pearson linear correlation " $r$ " to check the ratio of species increase with variations in fertility $(\mathrm{Mg}, \mathrm{P}, \mathrm{K}, \mathrm{Ca})$, acidity, aluminum content and soil drainage. Shapiro-Wilk (W) tested all the data distribution for normality. To test the use of variance (ANOVA), in addition to the normality test we tested the homoscedasticity of Levene.

To investigate the differences in the species richness of each physiognomy a rarefaction curve was employed (Colwell and Coddington 1994, Magurran 2004), and adjustments were made using the Mao Tau index with standard deviations 
at $95 \%$ confidence. This analysis was performed in the EstimateS 8.0 program, employing 100 randomizations to generate curves (Colwell 2006).

To analyze correlations between the environmental gradients (soil and drainage) and vegetation we used the Canonical Correspondence Analysis (CCA) (ter Braak 1987). For this analysis, we grouped vegetation data at every two plots. We used only species that had values greater than or equal to five individuals sampled. These data were correlated with eight chemical variables of soil: $\mathrm{pH}$ in $\mathrm{H} 20$, available phosphorus (P), exchangeable Calcium (Ca), Aluminum (Al), Sodium ( $\mathrm{Na}$ ), Magnesium (Mg), Potassium (K) and Organic Matter (MO). The soil physical attributes used for the CCA were the amounts of coarse sand, fine sand, silt and clay. The species were also correlated with drainage classes for each vegetation type. The program PC-ORD for Windows version 4.14 generated analyses and the ordered CCA axes (McCune and Mefford 1999). To check the significance level of the results given by the main axis of the canonical ordering, we employed the Monte Carlo permutation (ter Braak 1988, 1994).

To verify the relationships between species and environmental variables expressed by each forest type, we used the Indicator Species Analysis (Dufrêne and Legendre 1997) and the calculations were processed by PC-ORD for Windows version 4.14 (McCune and Mefford 1999). According to Machado et al. (2008), this method combines information on the abundance of a species in a certain group of sampling units, revealing information about the confidence of occurrence of this species in the same habitat. The results are expressed by the observed indicator value (OIV), in which the significance of data is given by the permutation test of Monte Carlo. Thus, only one species is considered an indicator of habitat when it has the highest OIV, and the, Monte Carlo test is significant at $\mathrm{p} \leq 0.05$ (Machado et al. 2008).

\section{RESULTS}

PHYSICAL ENVIRONMENT

The chemical and physical soil variables showed significant differences among soil classes in the four forest types (Table II). However, the major changes were observed between the Humusalluvial Spodosols (Transition Forest) compared to Melanic Gleysols (Inundated Forest) and Thiomorphic Histosols. The Quartzarenic Neossols were very close to Spodosols in terms of physical and chemical characteristics.

Soil drainage classes varied significantly between all formations (ANOVA, $\mathrm{P}<0.001$ ), reinforcing the importance of flooding in the sedimentary environment. The $\mathrm{pH}$ values were lower for the formations with greater influence of groundwater, following the highest values of exchangeable $\mathrm{Al}$ in these formations. Following the same pattern, the soil drainage gradient showed increasing concentrations of organic matter, sodium, potassium, magnesium, silt and clay as the soil becomes more subject to flooding. The variables with the highest values in Well-drained Forests were $\mathrm{pH}$ and coarse sand. However, all soils studied are dystrophic, with a very low fertility status.

The soils of Floodplain Forests and Inundated Forest showed higher levels of nutrients, with higher percentages of silt and clay; they were less leached than the sandier soils of the Well-drained uplands. Organic matter in these formations also exhibited significantly higher values when compared to the Well-drained Forest. This condition depends on the hydromorphic environment, since soil reduction and low oxygen condition slows downs organic matter decomposition.

\section{RICHNESS ANALYSIS}

In four forest types of PNMJ, 3804 individuals were sampled and 132 species identified. The Transition Forest had the greatest richness, with 82 species, followed by Well-drained Forest (74), Floodplain Forest (47) and Inundated Forest (29). 
TABLE II

Chemical and physical soil variables (0-10) in four forest types analyzed in Jacarenema Natural Municipal Park, Vila Velha, Brazil. $p$ = significance level. INF=Inundated Forest; FPF=Floodplain Forest; TRF=Transitional Forest; WDF=Well-drainedForest. Each line shows the value of the soil variable in each forest type. Similar letters denote values that could not be differentiated by the Tukey test $(p \leq 0.05)$.

\begin{tabular}{|c|c|c|c|c|c|}
\hline Soil variables & INF & FPF & TRF & WDF & $p$ \\
\hline $\mathrm{pH}$ in $\mathrm{H}_{2} \mathrm{O}$ & $4.73 \pm 0.23 \mathrm{a}$ & $4.35 \pm 0.26 b$ & $3.78 \pm 0.12 \mathrm{c}$ & $4.06 \pm 0.24 d$ & $* *$ \\
\hline $\mathrm{P}\left(\mathrm{mg} / \mathrm{dm}^{3}\right)$ & $2.45 \pm 0.57 \mathrm{a}$ & $5.11 \pm 2.07 b$ & $9.44 \pm 3.09 c$ & $9.37 \pm 2.40 c$ & $* *$ \\
\hline $\mathrm{K}\left(\mathrm{mg} / \mathrm{dm}^{3}\right)$ & $16.00 \pm 5.88 \mathrm{a}$ & $22.70 \pm 6.24 a$ & $55.80 \pm 16.17 b$ & $74.30 \pm 32.56 c$ & $* * *$ \\
\hline $\mathrm{Na}\left(\mathrm{mg} / \mathrm{dm}^{3}\right)$ & $6.89 \pm 5.42 \mathrm{a}$ & $8.69 \pm 4.68 \mathrm{a}$ & $60.90 \pm 12.76 b$ & $209.99 \pm 81.8 \mathrm{c}$ & $* *$ \\
\hline $\mathrm{Ca}\left(\mathrm{cmolc} / \mathrm{dm}^{3}\right)$ & $1.38 \pm 0.57 \mathrm{a}$ & $1.13 \pm 0.36 \mathrm{a}$ & $1.26 \pm 0.51 \mathrm{a}$ & $2.59 \pm 0.85 c$ & $* * *$ \\
\hline $\mathrm{Mg}\left(\mathrm{cmolc} / \mathrm{dm}^{3}\right)$ & $0.34 \pm 0.09 \mathrm{a}$ & $0.52 \pm 0.23 \mathrm{a}$ & $0.96 \pm 0.46 b$ & $2.72 \pm 0.85 \mathrm{c}$ & $* * *$ \\
\hline $\mathrm{Al}\left(\mathrm{cmolc} / \mathrm{dm}^{3}\right)$ & $0.19 \pm 0.17 \mathrm{a}$ & $0.87 \pm 0.64 b$ & $3.00 \pm 1.00 \mathrm{c}$ & $1.91 \pm 0.77 \mathrm{~d}$ & $* * *$ \\
\hline MO (dag/ $\left.\mathrm{Kg}^{-1}\right)$ & $2.39 \pm 0.52 \mathrm{a}$ & $5.07 \pm 2.81 \mathrm{a}$ & $35.07 \pm 12.12 b$ & $48.31 \pm 8.01 \mathrm{c}$ & $* * *$ \\
\hline Coarse sand (\%) & $90.00 \pm 1.03 \mathrm{a}$ & $88.00 \pm 2.34 \mathrm{a}$ & $42.50 \pm 13.68 b$ & $24.20 \pm 15.59 c$ & $* *$ \\
\hline Fine sand (\%) & $4.90 \pm 0.72 \mathrm{a}$ & $5.10 \pm 1.17 \mathrm{a}$ & $17.20 \pm 12.75 b$ & $5.50 \pm 4.52 \mathrm{a}$ & $* *$ \\
\hline Silt (\%) & $1.00 \pm 0.79 \mathrm{a}$ & $0.60 \pm 0.68 \mathrm{a}$ & $6.90 \pm 2.17 b$ & $16.70 \pm 3.92 \mathrm{c}$ & $* * *$ \\
\hline Clay (\%) & $4.10 \pm 1.07 \mathrm{a}$ & $6.30 \pm 2.60 \mathrm{a}$ & $33.40 \pm 9.01 b$ & $53.60 \pm 15.67 \mathrm{c}$ & $* * *$ \\
\hline
\end{tabular}

$* * \mathrm{p}<0.01 ; * * * \mathrm{p}<0.001$

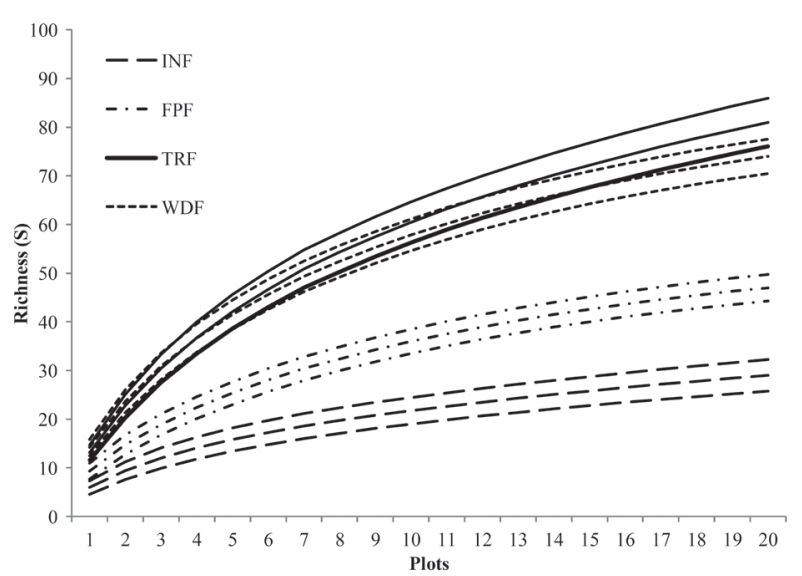

Figure 3 - Mao Tao rarefaction curves for the four forest formations in Jacarenema Natural Municipal Park, Vila Velha/ES. INF=Inundated Forest; FPF=Floodplain Forest; TRF=Transitional Forest; WDF=Welldrained Forest.

All forest formations showed significant differences in species richness (Tukey, $p<0.01$ ), except Well-drained Forest and Transition Forest, which showed no significant differences (Tukey test, $95 \%$ confidence). Corroborating these results, the rarefaction curves showed similar results reported by the Tukey test (Figure 3).
Changes in species richness among Restinga forests had statistically significant negative correlation with magnesium $(\mathrm{r}=-0.5822, \mathrm{p}=0.0001)$, phosphorus $(\mathrm{r}=-0.5739, \mathrm{p}=0.0001)$, potassium $(\mathrm{r}=-0.6418, \quad \mathrm{p}=0.0001), \quad$ calcium $\quad(\mathrm{r}=-0.357$, $\mathrm{p}=0.0001)$, sodium $(\mathrm{r}=-0.641, \mathrm{p}=0.0001)$ and aluminum ( $\mathrm{r}=-0.441, \mathrm{p}=0.0001)$, while acidity $(\mathrm{r}=-0.641, \quad \mathrm{p}=0.0001)$ had significant positive correlation with soil drainage $(\mathrm{r}=0.654, \mathrm{p}=0.0001)$.

VARIATION IN ABUNDANCE AND ANALYSIS OF INDICATOR SPECIES

For the ordination analysis (CCA) and the analysis of indicator species, 64 species were evaluated from a total of 132 due to the inclusion criteria established in the methodology (Table III). The eigenvalues found in the ordination analysis of chemical and physical variables of soil for the three axes were $0.848,0.326$ and 0.248 , for axes 1,2 and 3 , respectively (Table IV). The Pearson correlation was high for all three axes of the CCA (Table IV). Supporting this result, the Monte Carlo permutation 
TABLE III

Woody species used in Canonical Correspondence Analysis (CCA) and their abbreviations, for the four forests types studied in Jacarenema Natural Municipal Park, Vila Velha, Brazil. INF=Inundated Forest; FPF=Floodplain Forest; TRF $=$ Transitional Forest; WDF=Well-drained Forest.

\begin{tabular}{|c|c|c|c|c|c|c|}
\hline \multirow{2}{*}{ Species } & \multirow{2}{*}{ Family } & \multirow{2}{*}{ Abbreviations } & \multicolumn{4}{|c|}{ Abundance } \\
\hline & & & INF & FPF & TRF & WDF \\
\hline Alchornea triplinervia (Spreng.) Müll. Arg. & Euphorbiaceae & Alc tri & 21 & 10 & 0 & 1 \\
\hline Alibertia myrciifolia Spruce ex K. Schum. & Rubiaceae & Ali myr & 1 & 11 & 0 & 0 \\
\hline Andira fraxinifolia Benth. & Fabaceae & And fra & 2 & 2 & 4 & 1 \\
\hline Annona acutiflora & Annonaceae & Ann acu & 0 & 0 & 12 & 3 \\
\hline Annona acutiflora Mart. & Apocynaceae & Asp par & 0 & 0 & 2 & 5 \\
\hline Bactris setosa Mart. & Arecaceae & Bac set & 1796 & 335 & 26 & 0 \\
\hline Bactris vulgaris Barb. Rodr. & Arecaceae & Bac vul & 0 & 0 & 60 & 2 \\
\hline Brasilopuntia brasiliensis (Willd.) A. Berger & Cactaceae & Bra bra & 0 & 0 & 0 & 12 \\
\hline Buchenavia capitata (Vahl) Eichler & Combretaceae & Buc cap & 0 & 1 & 1 & 6 \\
\hline Byrsonima sericea DC. & Malpighiaceae & Byr ser & 0 & 0 & 5 & 0 \\
\hline Calophyllum brasiliense Cambess. & Clusiaceae & Cal bra & 8 & 2 & 1 & 0 \\
\hline Campomanesia guazumifolia (Cambess.) O. Berg & Myrtaceae & Cam gua & 0 & 0 & 3 & 16 \\
\hline Casearia commersoniana Cambess. & Salicaceae & Cas com & 0 & 5 & 6 & 2 \\
\hline Cathedra rubricaulis Miers & Olacaceae & Cat rub & 0 & 0 & 3 & 3 \\
\hline Chamaecrista ensiformis (Vell.) H.S. Irwin and Barneby & Fabaceae & Cha ens & 0 & 0 & 13 & 23 \\
\hline Coccoloba arborescens (Vell.) How & Polygonaceae & Coc arb & 0 & 0 & 3 & 5 \\
\hline Cupania emarginata Cambess. & Sapindaceae & Cup ema & 0 & 0 & 9 & 16 \\
\hline Cyathea phalerata Mart. & Cyatheaceae & Cya pha & 0 & 30 & 1 & 0 \\
\hline Dendropanax selloi Marchand & Araliaceae & Den sel & 0 & 18 & 5 & 0 \\
\hline Eugenia bahiensis DC. & Myrtaceae & Eug bah & 0 & 0 & 4 & 12 \\
\hline Eugenia excelsa O. Berg & Myrtaceae & Eug exc & 0 & 0 & 0 & 5 \\
\hline Eugenia sp. new & Myrtaceae & Eug nov & 11 & 0 & 0 & 0 \\
\hline Eugenia rostrata O.Berg & Myrtaceae & Eug ros & 0 & 0 & 10 & 55 \\
\hline Eugenia sulcata Spring ex Mart. & Myrtaceae & Eug sul & 0 & 0 & 0 & 6 \\
\hline Garcinia brasiliensis Mart. & Clusiaceae & Gar bra & 0 & 0 & 2 & 3 \\
\hline Geonoma schottiana Mart. & Arecaceae & Geo sch & 32 & 154 & 0 & 0 \\
\hline Gomidesia martiana O. Berg & Myrtaceae & Gom mar & 0 & 0 & 4 & 3 \\
\hline Guarea macrophylla Vahl & Meliaceae & Gua mac & 0 & 0 & 13 & 3 \\
\hline Guapira opposita (Vell.) Reitz & Nyctaginaceae & Gua opp & 0 & 2 & 5 & 0 \\
\hline Henriettea saldanhaei Cogn. & Melastomataceae & Hen sal & 0 & 10 & 0 & 0 \\
\hline Hymenaea rubriflora Ducke & Fabaceae & Hym rub & 0 & 0 & 1 & 6 \\
\hline Inga laurina Willd. & Fabaceae & Ing lau & 5 & 1 & 0 & 1 \\
\hline Jacaranda puberula Cham. & Bignoniaceae & Jac pub & 0 & 3 & 14 & 15 \\
\hline Kielmeyera albopunctata Saddi & Clusiaceae & Kie alb & 0 & 0 & 2 & 3 \\
\hline Kielmeyera membranacea Casar. & Clusiaceae & Kie mem & 0 & 0 & 6 & 3 \\
\hline Manilkara subsericea (Mart.) Dubard & Sapotaceae & Man sub & 0 & 0 & 4 & 3 \\
\hline Matayba guianensis Aubl. & Sapindaceae & Mat gui & 0 & 3 & 10 & 9 \\
\hline Maytenus obtusifolia Mart. & Celastraceae & May obt & 2 & 1 & 12 & 18 \\
\hline Miconia cinnamomifolia (DC.) Naudin & Melastomataceae & Mic cin & 4 & 4 & 0 & 0 \\
\hline
\end{tabular}


TABLE III (continuation)

\begin{tabular}{|c|c|c|c|c|c|c|}
\hline Miconia pusilliflora (DC) Naud & Melastomataceae & Mic pus & 0 & 0 & 6 & 0 \\
\hline Micropholis venulosa (Mart. and Eichler) Pierre & Sapotaceae & Mic ven & 0 & 1 & 1 & 11 \\
\hline Myrcia brasiliensis Kiaersk. & Myrtaceae & Myr bra & 0 & 5 & 3 & 0 \\
\hline Myrcia racemosa Barb. Rodr. & Myrtaceae & Myr rac & 3 & 2 & 0 & 0 \\
\hline Nectandra oppositifolia Nees & Lauraceae & Nec opp & 0 & 33 & 0 & 0 \\
\hline Nectandra psammophila Nees and Mart. & Lauraceae & Nec psa & 0 & 1 & 8 & 1 \\
\hline Ocotea lobbii (Meisn.) Rohwer & Lauraceae & Oco lob & 0 & 0 & 2 & 15 \\
\hline Ocotea notata (Nees) Mez & Lauraceae & Oco not & 0 & 1 & 10 & 13 \\
\hline Pera glabrata Baill. & Peraceae & Per gla & 0 & 5 & 9 & 6 \\
\hline Pouteria caimito (Ruiz and Pav.) Radlk. & Sapotaceae & Pou cai & 0 & 0 & 18 & 14 \\
\hline Pouteria coelomatica Rizzini & Sapotaceae & Pou coe & 0 & 0 & 0 & 15 \\
\hline Protium heptaphyllum (Aubl.) Marchand & Burseraceae & Pro hep & 0 & 19 & 95 & 50 \\
\hline Protium icicariba (DC.) Marchand & Burseraceae & Pro ici & 0 & 0 & 6 & 1 \\
\hline Pseudobombax grandiflorum (Cav.) A. Robyns & Malvaceae & Pse bom & 2 & 1 & 4 & 4 \\
\hline Psidium cattleyanum Sabine & Myrtaceae & Psi cat & 0 & 0 & 0 & 15 \\
\hline Qualea cryptantha (Spreng.) Warm. & Vochysiaceae & Qua cry & 27 & 12 & 0 & 0 \\
\hline Rauvolfia mattfeldiana Markgr. & Apocynaceae & Rau mat & 0 & 0 & 5 & 8 \\
\hline Rhodostemonodaphne capixabensis Baitello and Coe-Teixeira & Lauraceae & Rho cap & 0 & 10 & 13 & 0 \\
\hline Sapium glandulatum (Vell.) Pax & Euphorbiaceae & Sap gla & 19 & 6 & 0 & 0 \\
\hline Sloanea guianensis (Aubl.) Benth. & Elaeocarpaceae & Slo gui & 0 & 11 & 4 & 0 \\
\hline Symphonia globulifera L. f. & Clusiaceae & Sym glo & 11 & 91 & 15 & 0 \\
\hline Tapirira guianensis Aubl. & Anacardiaceae & Tap gui & 10 & 16 & 21 & 8 \\
\hline Thyrsodium spruceanum Benth. & Anacardiaceae & Thy spr & 0 & 0 & 9 & 0 \\
\hline Trichilia casaretti C. DC. & Meliaceae & Tri cas & 0 & 0 & 3 & 4 \\
\hline Zollernia glabra (Spreng.) Yakovlev & Fabaceae & Zol gla & 0 & 0 & 4 & 16 \\
\hline Total & & & 1954 & 806 & 477 & 421 \\
\hline
\end{tabular}

test indicated that the abundance of species varied significantly depending on the environmental variables. The eigenvalue higher than 0.5 in the first axis for the CCA is considered high (ter Braak 1995), indicating the existence of a long gradient with high species turnover in the direction of the gradient of soil and flooding.

The soil chemical variables with higher correlation on the first axis were organic matter, phosphorus, acidity, sodium, magnesium, potassium and aluminum (Table IV). The soil physical variables with the highest correlation were drainage, sand, clay and silt. Fine sand showed low correlation values, but it has influenced the separation of species and plots in the Humic Gleisols.
The proposed ordinances with chemical and physical data clearly separated plots according to their respective soils (Figure 4). Quartzarenic Neosols concentrated in the upper left quadrant, whereas Humic Spodosols were concentrated in the lower quadrant. Humic Gleisols are concentrated in the lower quadrants both to the left and right. Thionic Organosols are concentrated in the right upper quadrant, associated with Humic Gleisols.

These results show the existence of a gradient from right to left in the representation of the CCA, i.e., following Thionic Organosols from topographically lower areas (interdune), with higher organic matter content, exchangeable magnesium, sodium and potassium. Humic Gleisols are also in the interdune, 
TABLE IV

Results of the Canonical Correspondence Analysis (CCA) with 64 species in Jacarenema Natural Municipal Park, Vila Velha, Brazil.

\begin{tabular}{lccc}
\hline CCA & \multicolumn{3}{c}{ CCA } \\
\cline { 2 - 4 } Results & Axis 1 & Axis 2 & Axis 3 \\
\hline Eigenvalues & 0.848 & 0.326 & 0.248 \\
Total variance explained (\%) & 21.2 & 8.1 & 6.2 \\
Pearson Correlation - spp x Environmetal variables & 0.986 & 0.897 & 0.878 \\
Monte Carlo test - spp x Environmental variables & $* *$ & $* *$ & $* *$ \\
Correlations of internal variables: & & & \\
Coarse sand & 0.906 & 0.151 & 0.196 \\
Fine sand & -0.189 & 0.47 & -0.228 \\
Silt & -0.806 & -0.44 & -0.106 \\
Clay & -0.827 & -0.233 & -0.129 \\
Drainage & 0.958 & 0.02 & -0.254 \\
pH & 0.711 & -0.426 & -0.154 \\
Phosphorus & -0.745 & 0.169 & 0.019 \\
Potassium & -0.68 & -0.217 & -0.014 \\
Sodium & -0.691 & -0.456 & -0.093 \\
Calcium & -0.45 & -0.349 & -0.198 \\
Magnesium & -0.679 & -0.401 & -0.044 \\
Aluminum & -0.634 & 0.4 & 0.09 \\
Organic Matter & -0.893 & -0.084 & -0.141 \\
\hline
\end{tabular}

$* * \mathrm{p}<0.01$.

but are located at a topographically higher position compared to the former, so it is relatively less subject to flooding. It showed higher concentrations of phosphorus and aluminum. According to the gradient proposed by the ordination, the Humic Spodosols follow, situated at the dune border, with moderate drainage, intermediate concentration of nutrients and increasing coarse sand content. Quartzarenic Neossols are located on the upper dune with well-drained soils, moderately acid and lowest fertility status.

The results obtained with the CCA ordination suggest that the abundance of species is related to variations in physical and chemical attributes of soils (Figure 5). The test of indicator species using the 64 species analyzed in the CCA revealed that 42 species had a significant indicator value for some of the four types of forest soil studied (Table V). These results consistently demonstrate that edaphic factors control the distribution of species in coastal Restinga forests.
Plants associated with poorly drained soils, with higher percentages of silt and clay, salts and organic matter (Thionic Organosols) are Bactris setosa, Qualea cryptantha, Alchornea triplinervia, Calophyllum brasiliense, Sapium glandulatum, Myrcia racemosa, Inga laurina and Eugenia sp. This last species was identified as a new species (e.g. M.E.G. Sobral, unpublished data). In our area this species is restricted to the Inundated Forest, showing high abundance values and classified as an indicator species in this environment at Jacarenema Restinga.

On poorly drained, extremely acidic soil, with higher percentages of fine sand and with higher concentrations of phosphorus and aluminum (Humic Gleisols), typical species are Geonoma schottiana, Nectandra oppositifolia, Symphonia globulifera, Alibertia myrciifolia, Cyathea phalerata, Henriettea saldanhaei, Sloanea guianensis Dendropanax selloi and Myrcia brasiliensis. 


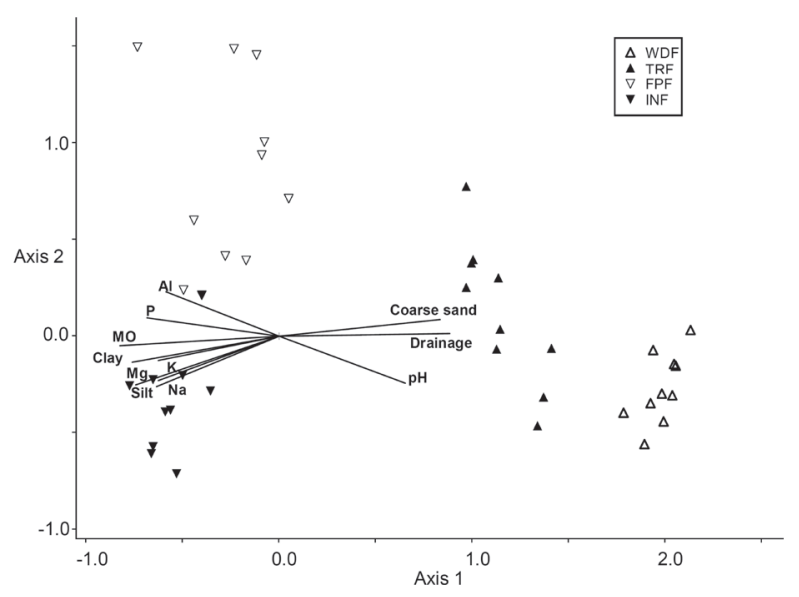

Figure 4 - Canonical Correspondence Analysis (CCA) of the 40 plots sampled and chemical soil features. INF=Inundated Forest; FPF $=$ Floodplain Forest; TRF=Transitional Forest; WDF=Welldrained Forest; $\mathrm{pH}=$ acidity in $\mathrm{H} 2 \mathrm{O} ; \mathrm{Na}=$ Sodium; $\mathrm{Mg}=$ Magnesium; $\mathrm{K}=$ Potassium; $\mathrm{P}=$ Phosphorus; $\mathrm{Al}=$ Aluminum; $\mathrm{MO}=$ Organic matter.

On the sandy border with intermediate characteristics of soil fertility and drainage (Humic Spodosols), typical plants are Protium heptaphyllum, Bactris vulgaris, Pouteria caimito, Guarea macrophylla, Miconia pusilliflora, Byrsonima sericea, Annona acutiflora, Jacaranda puberula, Protium icicariba, Rhodostemonodaphne capixabensis, Nectandra psammophila and Guapira opposita, amongst others.

On the highest dune segment with excessively drained soils, lower soil acidity, lower fertility and higher percentages of sand (Quartzarenic Neossols), the most abundant species were Eugenia rostrata, Ocotea lobbii, Campomanesia guazumifolia, Pouteria coelomatica, Psidium cattleyanum, Zollernia glabra, Chamaecrista ensiformis and Ocotea notata, amongst others.

\section{DISCUSSION}

The overall soil chemical fertility increased from topographically higher areas to the bottom of the landscape, having a positive relationship with increased soil flooding. Thus, this distribution is a typical pedological catena, or soil toposequence (Resende et al.1988, Sobieraj et al. 2002).
Variations in physical and chemical characteristics of surface soils are related to the sedimentary nature associated with different drainage conditions, considering that the most marked changes were related to different levels of flooding to which each forest environment is submitted (Jacomine 2004, EMBRAPA 2006). This condition can be further enhanced by some variation in chemical and physical properties of the soil between the two upland forests since both have the water table far from the surface, so that there is little contribution of groundwater to soil-surface characteristics. However, the levels of phosphorus, aluminum, $\mathrm{pH}$ and groundwater height were significantly different between these formations.

It is noteworthy that all forest tracts analyzed are closely related to distinct soils, and therefore significant differences in chemical, physical and morphological properties can be expected. Such differences are only revealed when soils are analyzed in greater depths (Magnago et al. 2010).

The great pedological heterogeneity observed between plots allocated on Thionic Organosols and Humic Gleisols probably occurred due to microtopographic variation of the floodplain, causing a patchy distribution of plants and flooding in the same area. Micro-topographic variation has been reported in other studies of floodplain forests in the Tropics (Ivanauskas et al. 1997, Toniato et al. 1998, Ivanauskas and Rodrigues 2000), and this is typical of the sedimentary floodplains.

The ecotonal character assigned to the Transition Forest is due to the occurrence of species found in flooded areas and in well-drained soils. This transitional floristic composition is matched by intermediate soil characteristics, both in terms of nutrient and groundwater level.

Although species richness in Transition Forest did not show values significantly different from the Well-drained Forest, the absolute result (82 species) agrees with Ashton (1990) and Tilman (1986), who reported that environments with intermediate nutrient availability have greater 


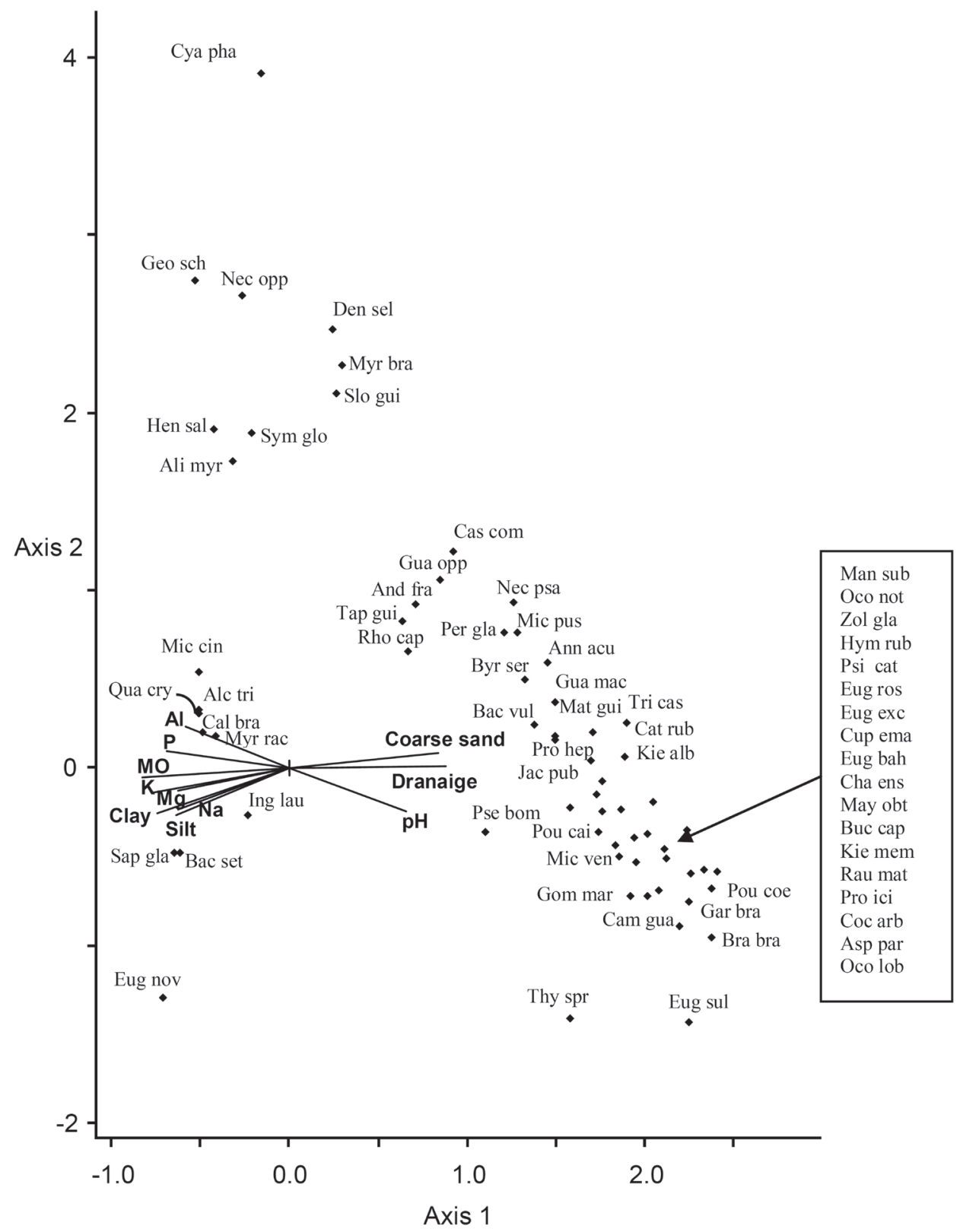

Figure 5 - Canonical Correspondence Analysis of species with the chemical soil features (CCA). Species names are listed in Table IV. $\mathrm{pH}=$ acidity in water, $\mathrm{Na}=$ sodium, $\mathrm{Mg}=$ Magnesium, $\mathrm{K}=$ Potassium, $\mathrm{P}=$ Phosphorus; $\mathrm{Al}=\mathrm{Aluminum} ; \mathrm{MO}=$ Organic matter.

species richness values than those at the extremes of nutrient availability. In our case, differences in soil characteristics and flooding may be not so great as to provide extreme variability in the species richness.

Waterlogging has been considered a determining factor in selecting plant species (Ivanauskas and Rodrigues 2000, Budke et al.
2007), which was confirmed by several studies that showed that species richness in wetland environments is very different from dry-land areas (Sugiyama and Mantovani 1994, Toniato et al. 1998, Romagnolo and Souza 2000, Sztutman and Rodrigues 2002). Several authors also stress that soil acidity and exchangeable aluminum are the 
TABLE V

Results of the indicator species analysis in four forests studied based on soil variables and cover value of 64 species in Jacarenema Natural Municipal Park, Vila Velha, Brazil. OIV=Observed indicator value; VIE=expected value indicator; $s=$ standard deviation, p=significance level; INF=Inundated Forest; FPF=Floodplain Forest; TRF=Transitional Forest; WDF=Well-drained Forest.

\begin{tabular}{|c|c|c|c|c|c|c|c|c|}
\hline \multirow{2}{*}{ Species } & \multirow{2}{*}{ OIV } & \multicolumn{3}{|c|}{ VIE } & \multicolumn{4}{|c|}{ Abundance (\%) } \\
\hline & & Average & $\mathbf{S}$ & $\mathbf{p}$ & INF & FPF & TRF & WDF \\
\hline \multicolumn{9}{|l|}{ Thiomorphic Histosols - INF } \\
\hline Bactris setosa & 83.3 & 22.1 & 4.16 & $* * *$ & 83 & 16 & 1 & 0 \\
\hline Qualea cryptantha & 45 & 12.6 & 4.22 & $* * *$ & 69 & 31 & 0 & 0 \\
\hline Alchornea triplinervia & 39.4 & 12.7 & 3.95 & $* * *$ & 66 & 31 & 0 & 3 \\
\hline Eugenia sp nov, & 35 & 7.5 & 3.54 & $* * *$ & 100 & 0 & 0 & 0 \\
\hline Sapium glandulatum & 30.4 & 9.7 & 4.16 & $* *$ & 76 & 24 & 0 & 0 \\
\hline Calophyllum brasiliense & 25.5 & 8.6 & 3.52 & $* *$ & 73 & 18 & 9 & 0 \\
\hline Inga laurina & 17.9 & 7.4 & 3.59 & $*$ & 71 & 14 & 0 & 14 \\
\hline \multicolumn{9}{|l|}{ Melanic Gleysols - FPF } \\
\hline Geonoma schottiana & 74.5 & 15.4 & 4.86 & $* * *$ & 17 & 83 & 0 & 0 \\
\hline Nectandra oppositifolia & 65 & 10.4 & 4.11 & $* * *$ & 0 & 100 & 0 & 0 \\
\hline Symphonia globulifera & 62.2 & 15.5 & 4.68 & $* * *$ & 9 & 78 & 13 & 0 \\
\hline Alibertia myrciifolia & 36.7 & 8.6 & 3.76 & $* * *$ & 8 & 92 & 0 & 0 \\
\hline Cyathea phalerata & 29 & 8.6 & 4.3 & $* *$ & 0 & 97 & 3 & 0 \\
\hline Henriettea saldanhaei & 20 & 6.7 & 3.76 & $* *$ & 0 & 100 & 0 & 0 \\
\hline \multicolumn{9}{|l|}{ Humic Spodosols - TRF } \\
\hline Protium heptaphyllum & 52.1 & 21.2 & 4.36 & $* * *$ & 0 & 12 & 58 & 30 \\
\hline Bactris vulgaris & 48.4 & 10.3 & 4.25 & $* * *$ & 0 & 0 & 97 & 3 \\
\hline Pouteria caimito & 30.9 & 13.3 & 3.98 & $* *$ & 0 & 0 & 56 & 44 \\
\hline Guarea macrophylla & 28.4 & 9.1 & 3.88 & $* *$ & 0 & 0 & 81 & 19 \\
\hline Miconia pusilliflora & 25 & 6.5 & 3.37 & $* *$ & 0 & 0 & 100 & 0 \\
\hline Byrsonima sericea & 25 & 6.3 & 3.46 & $* *$ & 0 & 0 & 100 & 0 \\
\hline Annona acutiflora & 24 & 8.5 & 3.65 & $* *$ & 0 & 0 & 80 & 20 \\
\hline Jacaranda puberula & 21.9 & 12.9 & 4.23 & $*$ & 0 & 9 & 44 & 47 \\
\hline Protium icicariba & 21.4 & 7.1 & 3.53 & $* *$ & 0 & 0 & 86 & 14 \\
\hline Rhodostemonodaphne capixabensis & 19.8 & 9.7 & 4.17 & $*$ & 0 & 43 & 57 & 0 \\
\hline Nectandra psammophila & 16 & 7 & 3.49 & $*$ & 0 & 10 & 80 & 10 \\
\hline \multicolumn{9}{|l|}{ Quartzarenic Neossols - WDF } \\
\hline Eugenia rostrata & 67.7 & 13.1 & 3.99 & $* * *$ & 0 & 0 & 15 & 85 \\
\hline Ocotea lobbii & 48.5 & 10.3 & 3.87 & $* * *$ & 0 & 0 & 12 & 88 \\
\hline Campomanesia guazumifolia & 46.3 & 10.5 & 3.83 & $* * *$ & 0 & 0 & 16 & 84 \\
\hline Pouteria coelomatica & 45 & 8.8 & 3.79 & $* * *$ & 0 & 0 & 0 & 100 \\
\hline Psidium cattleyanum & 45 & 8.5 & 3.58 & $* * *$ & 0 & 0 & 0 & 100 \\
\hline Zollernia glabra & 44 & 10.9 & 3.72 & $* * *$ & 0 & 0 & 20 & 80 \\
\hline Chamaecrista ensiformis & 31.9 & 13.7 & 4.78 & $* *$ & 0 & 0 & 36 & 64 \\
\hline Ocotea notate & 29.8 & 11.6 & 3.98 & $* *$ & 0 & 4 & 42 & 54 \\
\hline Rauvolfia mattfeldiana & 24.6 & 9.8 & 3.74 & $* *$ & 0 & 0 & 38 & 62 \\
\hline Cupania emarginata & 22.4 & 11.1 & 4.27 & $*$ & 0 & 0 & 36 & 64 \\
\hline Eugenia excelsa & 20 & 6.1 & 3.32 & $* *$ & 0 & 0 & 0 & 100 \\
\hline Eugenia sulcata & 20 & 6.3 & 3.27 & $* *$ & 0 & 0 & 0 & 100 \\
\hline
\end{tabular}


TABLE V (continuation)

\begin{tabular}{lcccccccc}
\hline Eugenia bahiensis & 18.7 & 8.8 & 4.4 & $*$ & 0 & 0 & 25 & 75 \\
Buchenavia capitata & 18.7 & 7.5 & 3.47 & $*$ & 0 & 12 & 12 & 75 \\
Aspidosperma parvifolium & 17.9 & 7.2 & 3.25 & $* *$ & 0 & 0 & 29 & 71 \\
Hymenaea rubriflora & 17.1 & 6.5 & 3.2 & $*$ & 0 & 0 & 14 & 86 \\
Micropholis venulosa & 16.9 & 7.4 & 3.69 & $*$ & 0 & 8 & 8 & 85 \\
Brasilopuntia brasiliensis & 15 & 5.3 & 3.07 & $*$ & 0 & 0 & 0 & 100 \\
\hline$* \mathrm{p} \leq 0.05 ; * * \mathrm{p} \leq 0.01 ; * * \mathrm{p} \leq 0.001$. & & & & & & & &
\end{tabular}

important limiting factors for the establishment of plant species (Lathwell and Grove 1986, Sollins 1998, Grime 2001).

Exchangeable sodium is commonly high in flooded environments near to the beaches which also, according with (Larcher 2000), turns out to be limiting to plant species. Considering the above mentioned points, the variation in species richness and floristic heterogeneity found among the forests studied here significantly imposes selectivity by the most limiting characteristics in the wetlands when compared to non-flooded forest areas.

The highest levels of organic matter in poorly drained areas also suggest a prominent role in plant distribution in this environment. Even mounds and small vegetation islands on piles of plant debris appear to be favorable microenvironments for the development of certain species over others, in such a way that the organic matter has been correlated with the distribution of vegetation types and abundance of species in different coastal environments subject to flooding (Budke et al. 2007, Munhoz et al. 2008).

In spite of higher organic matter content and higher fertility, environmental conditions in flooded areas are very limiting to the establishment of species in this forest floodplain, in function of the low oxygen availability combined with higher salt concentration.

The negative correlation between richness and soil fertility and positive correlation between richness and drainage suggest that since the Floodplain Forests have flooded soils with higher fertility, floodtolerant species would be more competitive, resulting in higher abundance of species, with ecological dominance and lower richness. This condition is similar to one found in monodominant forests of Vochysia divergens in the Pantanal wetlands of Brazil, where values for this species greatly increase with flooding, accompanied by a decrease in species richness (Arieira and Cunha 2006). In this regard, Nascimento and Villela (2006) reported an increased dominance of Peltogyne gracilipes related to increasing magnesium in the soil, thus excluding other species through competition. According to Scarano (2002), this high dominance of a few species can be considered typical of extreme environments.

In floodplain forests, the species Bactris setosa, Alchornea triplinervia, Calophyllum brasiliense, Sapium glandulatum, Geonoma schottiana, Symphonia globulifera, Nectandra oppositifolia and Myrcia brasiliensis are generally the most common (Araujo et al. 1998, 2004, Sztutman and Rodrigues 2002, Dorneles and Waechter 2004, Menezes-Silva and Britez 2005, Menezes and Araujo 2005, Guedes et al. 2006, Carvalho et al. 2006, Martins et al. 2008). Less frequent, but also present in studies of floodplain forests are Sloanea guianensis, Alibertia myrciifolia, Qualea cryptantha, Myrcia racemosa and Cyathea phalerata (Behar and Viégas 1992, Galvão et al. 2002, Goldenberg 2004, Guedes et al. 2006, Sacramento et al. 2007, Martins et al. 2008).

The species present in the Well-drained and Transition Forests are mentioned as being common in similar environments in studies elsewhere (Assis et al. 2004, Fabris and César 1996, Araujo et al. 1998, 2004, Menezes and Araujo 2005, Assumpção and Nascimento 2000, Pereira and Assis 2000, 
Menezes-Silva and Britez 2005). Some species that occurred in Transition Forest such as Calophyllum brasiliense, Alchornea triplinervia, Nectandra oppositifolia and Guarea macrophylla are among the most common in floristic and phytosociological studies of the Brazilian Riparian forests outside Amazonia (Rodrigues and Nave 2004).

The distribution of the species in the CCA and Indicator Species analyses are consistent with that in the literature. Thus, we infer that these species are indicators of soil conditions (soil types and groundwater level) imposed at each community analyzed, showing greatest abundance where environmental conditions are more favorable for their establishment and development.

The results for the Restinga forests of Jacarenema corroborate those proposed for Riparian forests, which are marked by high plant-species richness (Rodrigues and Nave 2004), accompanied by a significant gradient of soil and drainage (Jacomine 2004).

We found that changes in the floristic composition, richness and species abundance that make up the different forest types form, together with soil and drainage variation, form a complex and heterogeneous enviroment that is characteristic of tropical floodplain/riverine forests.

Thus, we can infer that in the Restinga forests the amounts of aluminum, sodium, and organic matter, as well as soil acidity and flooding regime are the most important determining factors controlling plant richness. Flooding seems to be a more limiting factor for the establishment of plant species than soil fertility attributes.

\section{ACKNOWLEDGMENTS}

We are grateful to Coordenação de Aperfeiçoamento de Pessoal de Nível Superior (CAPES) for granting the scholarship to the first author; to Mariana F. Rocha, Fabio A. Matos, Guilherme Resende, Herivelton Borges, Vinicius Cordeiro (Vico), Geanna Correia, Marcelo Belisário and André Assis, among others, for great assistance in field activities, to the prefecture of Vila Velha for the authorization of this study in the area of Jacarenema Natural Municipal Park, and to Dorothy Sue Dunn de Araujo for reviewing this manuscript. This manuscript is part of the Master's degree dissertation of the first author.

\section{RESUMO}

O objetivo deste estudo foi o de determinar as mudanças na composição, abundância e riqueza de espécies ao longo de um gradiente de floresta com variações de solo e inundações. As florestas localizam-se na margem esquerda do Rio Jucu, no Parque Natural Municipal de Jacarenema, Espírito Santo. O levantamento das espécies arbustivo/arbóreas foi realizado em 80 parcelas de $5 \times 25 \mathrm{~m}$, distribuídas equitativamente entre as florestas estudadas. Foram incluídos na amostragem todos os indivíduos com $\geq 3,2 \mathrm{~cm}$ diâmetro à altura do solo $(1,30 \mathrm{~m})$. Foram coletadas amostras de solo superficial $(0-10 \mathrm{~cm})$ em cada parcela para análise química e física. Os resultados mostraram a existência de gradiente pedológico significativo, que é influenciado pelas variações sazonais do lençol freático. As formações florestais da Restinga apresentaram diferenças significativas na riqueza de espécies, com exceção da Floresta Não Inundável em relação a Floresta Não Inundável de Transição. A Análise de Correlação Canônica (CCA) mostrou que algumas espécies apresentam sua distribuição ao longo do gradiente sob influência da drenagem, das concentrações de nutrientes e das características físicas dos solos. Entre as variáveis testadas, a inundação parece ser o fator mais limitante para o estabelecimento de espécies vegetais nas florestas de Restinga do que os atributos básicos de fertilidade do solo.

Palavras-chave: Vegetação, Florestas inundadas, Ecossistema costeiro, Solos arenosos, Depósitos quaternários, Influência Marinha, Florestas Ciliares.

\section{REFERENCES}

APG II - Angiosperm Phylogeny Group. 2003. An update of the Angiosperm Phylogeny Group classification for the orders and families of flowering plants: APG II. Bot J Linn Soc 141: 399-436. 
Araujo DSD, Pereira MCA AND Pimentel MC. 2004. Flora e estrutura de comunidades no Parque Nacional da Restinga de Jurubatiba - Síntese dos conhecimentos com enfoque especial para a formação aberta de Clusia. In: ROCHA CFD AND SCARANO FR (Orgs), Ecologia, História Natural e Conservação do Parque Nacional da Restinga de Jurubatiba. RiMa, São Carlos, São Paulo, p. 59-76.

Araujo DSD, Scarano FR, SÁ CF, Kurtz BC, Zaluar HLT, Montezuma RCM AND OliveIRA RC. 1998. Comunidades Vegetais do Parque Nacional da Restinga de Jurubatiba. In: ESTEVES FA (Ed), Ecologia das Lagoas Costeiras do Parque Nacional da Restinga de Jurubatiba e do Município de Macaé, RJ. Universidade Federal do Rio de Janeiro, Rio de Janeiro, p. 39-62.

ARIEIRA J AND CUNHA CN. 2006. Fitossociologia de uma floresta inundável monodominante de Vochysia divergens Pohl (Vochysiaceae), no Pantanal Norte, MT, Brasil. Acta Bot Bras 20(3): 569-580.

AsHTON PS. 1990. Species richness in tropical forests. In: HOLM-NIELSEN LB, NIELSEN IC AND BALSLEV H (Eds), Tropical forests - botanical dynamics, speciation and diversity. Academic Press, London, p. 239-251.

Assis AM, Thomaz LD AND Pereira OJ. 2004. Florística de um trecho de floresta de Restinga no município de Guarapari, Espírito Santo, Brasil. Acta Bot Bras 18(1): 191-201.

AsSUMPÇÃO J AND NASCIMENTO MT. 2000. Estrutura e composição florística de quatro formações vegetais de Restinga no complexo lagunar Grussaí/Iquipari, São João da Barra, RJ, Brasil. Acta Bot Bras 14(3): 301-315.

BeHAR L AND ViÉGAs GMF. 1992. Pteridophyta da Restinga do Parque Estadual de Setiba, Espírito Santo. Bol Mus Biol Mello Leitão 1: 39-59.

BUdKE JC AND JARENKOW JA, OLIVEIRA-FILHO AT. 2007. Relationships between tree component structure, topography and soils of a riverside forest, Rio Botucaraí, Southern Brazil. Plant Ecol 189: 187-200.

Carvalho FA, NAscimento MT, Braga JMA AND RODRIGUES PJFP. 2006. Estrutura da Comunidade Arbórea da Floresta Atlântica de Baixada Periodicamente Inundada na Reserva Biológica de Poço das Antas, Rio de Janeiro, Brasil. Rodriguésia 57(3): 503-518.

Clark DB, Palmer MW and Clark DA. 1999. Edaphic factors and the landscape-scale distributions of tropical rain forest trees. Ecology 80(8): 2662-2675.

COLWELL RK. 2006. Estimates: Statistical estimation of species richness and shared species from samples. Version 8.0. User's Guide and application published at: http://purl.oclc. org/estimates.

COLWELL RK AND CODDINGTON JA. 1994. Estimating terrestrial biodiversity through extrapolation. Philosl T Roy Soc B 345: 101-118.

Coutinho LM. 2006. O conceito de bioma. Acta Bot Bras 20(1): 13-23.

DORNELES LPP AND WAEChTER JL. 2004. Fitossociologia do componente arbóreo na floresta turfosa do Parque Nacional da Lagoa do Peixe, Rio Grande do Sul, Brasil. Acta Bot Bras 17(4): 815-824.
DUFRÊNE M AND LEGENDRE P. 1997. Species assemblages and indicator species: the need for a flexible asymmetrical approach. Ecol Monogr 67: 345-366.

EMBRAPA. 2006. Sistema brasileiro de classificação de solos. ( $2^{\text {nd }}$ edition). EMBRAPA Solos, Rio de Janeiro.

FABRIS LC AND CÉSAR O. 1996. Estudos florísticos em uma mata litorânea no sul do estado do Espírito Santo. Bol Mus Biol Mello Leitão 5: 15-46.

FERreira-Junior WG, Silva AF, SchaEFER CEGR, MEIRA Neto JAA, DiAs AS, IGNÁCIO M AND MEdEIROS MCMP. 2007. Influence of soils and topographic gradients on tree species distribution in a Brazilian Atlantic Tropical Semideciduous Forest. Edinb J Bot 64(2): 137-157.

GALVÃo F, RODERJAN CV, KUNIYOSHI YS AND ZILLER SR. 2002. Composição florística e fitossociologia de caxetais do litoral do Estado do Paraná - Brasil. Floresta 32(1): 19-42.

GoldenberG R. 2004. O gênero Miconia (Melastomataceae) no Estado do Paraná, Brasil. Acta Bot Bras 18(4): 927-947.

GRIME JP. 2001. Plant strategies, vegetation processes, and ecosystem properties. ( $2^{\text {nd }}$ edition). Wiley, Chichester, UK.

Guedes D, BARBOSA LM AND MARTINS SE. 2006. Composição florística e estrutura fitossociológica de dois fragmentos de floresta de Restinga no Município de Bertioga, SP, Brasil. Acta Bot Bras 20(2): 299-311.

IPEMA - InSTITUTO DE PESQUisas dA MATA AtLÂNTICA. 2005. Conservação da Mata Atlântica no Estado do Espírito Santo: cobertura florestal e unidades de conservação. IPEMA, Vitória, Espírito Santo.

IVANAUSKAS NM AND RODRIGUES RR. 2000. Florística e fitossociologia de remanescentes de floresta estacional decidual em Piracicaba, São Paulo, Brasil. Rev Bras Bot 23(3): 291-304.

IVANAUSKAS NM, Rodrigues RR AND NAVE AG. 1997. Aspectos ecológicos de um trecho de Floresta de brejo em Itatinga, SP: florística, fitossociologia e seletividade de espécies. Rev Bras Bot 20(2): 139-153.

JACOMINE PKT. 2004. Solos sob matas ciliares. In: RODRIGUES RR AND LEITÃO-FILHO HF (Eds), Matas ciliares: conservação e recuperação. EDUSP/FAPESP, São Paulo, p. 27-32.

LARCHER W. 2000. Ecofisiologia Vegetal. São Carlos: Rima Artes e Textos, $531 \mathrm{p}$.

LATHWELl DJ AND GROVE TL. 1986. Soil-Plant Relationships in the Tropics. Ann Rev Ecol Syst 17: 1-16.

Machado ELM, Oliveira-Filho AT, VAN DEN Berg E, Carvalho WAC, Souza JS, Marques JJGSM AND CAlegário N. 2008. Efeitos do substrato, bordas e proximidade espacial na estrutura da comunidade arbórea de um fragmento florestal em Lavras, MG. Rev Bras Bot 31(2): 287-302.

MAgnago LFS, MARTINS SV, Schaefer CEGR AND NERI AV. 2010. Gradiente fitofisionômico-edáfico em formações florestais de Restinga no Sudeste do Brasil. Acta Bot Bras 24(4): 653-665.

MAGURRAN AE. 2004. Measuring biological diversity. Blackwell Science, Ltd. USA, Oxford.

Martin L, Suguio K, Dominguez JML and Flexor JM. 1997. Geologia do Quaternário costeiro do litoral norte do Rio de Janeiro e do Espírito Santo. CPRM/FAPESP, Belo Horizonte, $112 \mathrm{p}$. 
Martins SE, Rossi L, SAMPAio PSP AND MAGEntA MAG. 2008. Caracterização florística de comunidades vegetais de Restinga em Bertioga, SP, Brasil. Acta Bot Bras 22(1): 249-274.

MCCUNE B AND MEFFORD MJ. 1999. Multivariate analysis of ecological data. MjM Software, Gleneden Beach.

MENEZES LFT AND ARAUJO DSD 2005. Formações vegetacionais da Restinga da Marambaia, Rio de Janeiro. In: MENEZES LFT, PEIXOTO AL AND ARAUJO DSD (Orgs), História natural da Marambaia. EDUR, Rio de Janeiro, p. 67-120.

MENEZES-SiLva SM AND BRITEZ RM. 2005. A Vegetação da Planície Costeira. In: MARQUES MCM AND BRITEZ RM (Orgs), História Natural e Conservação da Ilha do Mel. Editora UFPR, Curitiba, p. 49-84.

Mueller-Dombois D AND Ellenberg H. 1974. Aims and methods of vegetation ecology. J Wiley \& Sons, New York, $547 \mathrm{p}$.

Munhoz CBR, Felfili JM AND Rodrigues C. 2008. Speciesenvironment relationship in the herb-subshrub layer of a moist Savanna site, Federal District, Brazil. Braz J Biol 68(1): 25-35.

NASCIMENTO MT AND VILLELA DM. 2006. Diversidade arbórea em florestas tropicais úmidas e o paradigma da monodominância. In: MARIATH JEA AND SANTOS RP(Orgs), Os avanços da botânica no início do século XXI: morfologia, fisiologia, taxonomia, ecologia e genética: conferências plenárias e simpósios do $57^{\circ}$ Congresso de Botânica. Soc Bras Bot, Porto Alegre, p. 373-377.

Oliveira-Filho AT, Vilela EA, CARVAlho DA AND GAVILANES ML. 1994. Effects of soils and topography on the distribution of tree species in a tropical riverine Forest in south-eastern Brazil. J Trop Ecol 10: 483-508.

PEREIRA OJ. 2003. Restinga: origem, estrutura e diversidade. In: JARDIM MG, BASTOS MNC AND SANTOS JUM (Orgs), Desafios da Botânica Brasileira no Novo Milênio: inventário, sistematização e conservação da biodiversidade vegetal. Soc Bras Bot, Belém, Pará, p. 177-179.

Pereira OJ AND Assis AM. 2000. Florística da Restinga de Camburi. Acta Bot Bras 14(1): 99-111.

PetTy AM AND Douglas MM. 2010. Scale relationships and linkages between woody vegetation communities along a large tropical floodplain river, north Australia. J Trop Ecol 26:79-92

REIS RCC. 2006. Palmeiras (Arecaceae) das Restingas do Estado do Rio de Janeiro, Brasil. Acta Bot Bras 20(3): 501-512.

REsende M, CuRi N AND SANTANA DP. 1988. Pedologia e fertilidade do solo: interações e interpretações. Ministério da Agricultura, Brasília, e Universidade Federal de Lavras, Lavras, $81 \mathrm{p}$.

RODRIGUES RR AND NAVE AA. 2004. Heterogeneidade florística das Matas Ciliares. In: RODRIGUES RR AND LEITÃOFILHO HF (Eds), Matas ciliares: conservação e recuperação. ( $2^{\mathrm{a}}$ edição). EDUSP/FAPESP, São Paulo, p. 45-71.

Romagnolo MB AND SouZA MC. 2000. Análise florística e estrutural de florestas ripárias do Alto Rio Paraná, Taquaruçu, MS. Acta Bot Bras 14(2): 163-174.
SACRAMENTO AC, ZICKEL CS AND ALMEIDA-JUNIOR EB. 2007. Aspectos florísticos da vegetação de Restinga no litoral de Pernambuco. Rev Árvore 31(6): 1121-1130.

SCARANO FR. 2002. Structure, Function and Floristic Relationships of Plant Communities in Stressful Habitats Marginal to the Brazilian Atlantic Rainforest. Ann BotLondon 90: 517-524.

SobIERAJ JA, ElsENBEER H AND COELHO RM AND NEWTON B. 2002. Spatial variability of soil hydraulic conductivity along a tropical rainforest catena. Geoderma 118(1-2): 79-90.

SOLLINS P. 1998. Factors influencing species composition in tropical lowland rain forest: does soil matter? Ecology 79(1): 23-30.

SugIYAma M AND MANTOVAnI W. 1994. Fitossociologia de um trecho de mata de Restinga na Ilha do Cardoso, SP. In: Anais do III Simpósio de Ecossistemas da Costa Brasileira - subsídios a um gerenciamento costeiro. $\left(2^{\mathrm{O}}\right.$ volume). ACIESP, São Paulo, p. 49-57.

SUGUIOKANDTESSLERMG. 1984.Planícies decordõesarenosos Quaternários do Brasil: origem e nomenclatura. In: LACERDA LD, ARAUJO DSD AND CERQUEIRA R (Orgs), Restingas: origem, estruturas e processos. CEUFF, Universidade Federal Fluminense, Niterói, p. 15-26.

SZTUTMAN M AND RodRigues RR. 2002. O mosaico vegetacional numa área de floresta contínua da planície litorânea, Parque Estadual da Campina do Encantado, Pariquera - Açu, SP. Rev Bras Bot 25(2): 61-176.

TER BRAAK CJF. 1987. The analysis of vegetation-environment relationship by Canonical Correspondence Analysis. Vegetatio 69: 69-77.

TER BRAAK CJF. 1988. CANOCO - A FORTRAN program for canonical community ordination by (Partial) (Detrended) (Canonical) Correspondence Analysis and redundancy analysis, version 2.1 Technical report LWA-88-2, TNO. Institute of Applied Computer Science, Wageningen.

Ter BraAK CJF. 1994. Canonical Community Ordination. Part I: basic theory end linear methods. Écoscience 1(2): 127-140.

TER BRAAK CJF. 1995. Ordination. In: JONGMAN RHG, TER BRAAK CJF AND VAN TONGEREN OFR (Eds), Data analysis in community and landscape ecology. University Press Cambridge, Cambridge, p. 91-173.

Ter BRAaK CJF AND PREnTICE C. 1988. A theory of gradient analysis. Advance in ecological research: classic papers 18: 271-317.

TILMAN D. 1986. Evolution and differentiation in terrestrial plant communities: the importance of the soil resource: light gradient. In: DIAMOND J AND CASE TJ (Eds), Community ecology. Harper and Row, New York, p. 359-380.

TONIATO MTZ, LEITÃo-FILHO HF AND RODRIGUES RR. 1998. Fitossociologia de um remanescente de floresta higrófila (Mata de brejo) em Campinas, SP. Rev Bras Bot 21(2): 197-210. 